\title{
Gastrintestinal Helminths of Capybara (Hydrochoerus hydrochaeris, Linnaeus, 1766) in Cattle Breeding Farm in the Area of the Ecological Reserve of Taim, Rio Grande
}

\author{
Afonso Lodovico Sinkoc ${ }^{1 *}$, João Guilherme Werner Brum ${ }^{2}$ and Gertrud Muller ${ }^{2}$ \\ ${ }^{I}$ Departamento de Clínica Médica Veterinária; Universidade Federal do Mato Grosso; Av. Fernando Correa da \\ Costa, s/ $n^{\circ}$; Campus Universitário; 78060-900; Cuiabá - MT - Brasil. ${ }^{2}$ Departamento de Microbiologia e \\ Parasitologia; Instituto de Biologia; Universidade Federal de Pelotas; Pelotas - RS - Brasil
}

\begin{abstract}
The aim of this study was we observe the prevalence, intensity and mean intensity of theinfection by gastrintestinal helminths in capybaras. The helminths collected resulted in the following relationship with their respective prevalence and mean intensities of infection: Strongyloides $s p$. - 62.55\% and 168.67; Protozoophaga obesa 95.83\% and 2698.26; Vianella hydrochoeri - 70.83\% and 83.82; Hydrochoerisnema anomalobursata - 58.33\% and 57.86; Capillaria hydrochoeri - 83.33\% and 35.25; Trichuris spp. - 50.00\% and 36.58; Hippocrepis hippocrepis 62.50\% and 22.40; Taxorchis schistocotyle $-12.50 \%$ and 2.33; Hydrochoeristrema cabrali $-45.83 \%$ and 10.73; Monoecocestus hydrochoeri - 50,00\% and 28.25 and Monoecocestus jacobi $-41.67 \%$ and 5.40. The helminths M. hydrochoeri, Strongyloides sp., Trichuris spp., H. hippocrepis and H. cabrali showed a statistical differences between ages in the mean intensity of parasitism, and the first two presented higher values for the young animals and the last three for the adults.
\end{abstract}

Key words: Hydrochoerus hydrochaeris, Helminths, Capybara

\section{INTRODUCTION}

The capybara (Hydrochoerus hydrochaeris, Linnaeus, 1766) is the world's largest rodent, present in South and Central America, living in forests with dense vegetation near to water, like lakes, rivers, streams and swamps, showing a frequent relative occurrence in many places in the State of Rio Grande do Sul (Silva, 1994). The economical exploitation of capybara is possible through the handling in natural areas, in partly confined and in intensive creation. However among the wildlife animals and in partly natural creation in the State of Mato Grosso (Brazil), the mortality is high, because the competition for the food besides the other ones and the diseases, like the parasitics (Alho et al., 1987a). The creation in partly natural areas has found difficulties by the behavior of these animals, which leads to stress condition, increasing their susceptibility to diseases like helminthosis and tripanosomosis (Alho et al.,1987b).

The investigation of helminths in capybara of Brazil has been subject of wildlife population (Nascimento et al., 1991; Costa and Catto, 1994; Sinkoc et al., 1995) and captivity animals (Mattos Jr. and Sanavria, 1993; Mattos Jr. et al., 1993; Ribeiro, 2002; Sinkoc et al., 2004). In the American continent, Venezuela Salas and Herrera (2004), in Argentina, Sutton et al. (1995) and

\footnotetext{
* Author for correspondence: alsinkoc@gmail.com
} 
Bolivia Casas et al. (1995)stabelished their studies. The aim of this investigation was know the gastrintestinal helminths of capybaras in exploitation areas of cattle breeding farm in the ecological reserve of Taim, Rio Grande, RS, Brazil.

\section{MATERIALS AND METHODS}

Between June and December of 1996, 24 capybaras were selected and divided in two groups, young $(\mathrm{n}=12)$, weight between 13 and 22 $\mathrm{Kg}$, and adult $(\mathrm{n}=12)$ weight between 30 and 45 $\mathrm{Kg}$. The procedures for necropsy, collection and fixation of the gastrintestinal material were made by the technique described for the study of helminths in ruminants with modification (Ueno and Gonçalves, 1994). The identification of the helminths are described in Sinkoc (1997). The helminths were identified according Skrjabin et al., (1964) and Yamaguti (1971) for trematodes, Yamaguti (1959) for cestodes and, Yamaguti (1961), Anderson and Chabaud (1983), Anderson et al. (1974-82) for nematodes.
The prevalence, intensity, mean intensity and abundance were calculated according to Margolis et al. (1982). For the estimative of mean intensity, the comparison was made by Wilcoxon's test for two samples of non parametric values and the prevalence ranges by the Qui-Square test with significance level of 5\%. To establish the higher, lower and intermediate levels, the species were observed, for each parameter when they showed the highest and lowest values, were tested statistically.

\section{RESULTS}

Nine species of helminths were identified: Protozoophaga obesa, Vianella hydrochoeri, Hydrochoerisnema anomalobursata, Capillaria hydrochoeri, Strongyloides sp., Trichuris spp., Hippocrepis hippocrepis, Taxorchis schistocotyle, Hydrochoeristrema cabrali, Monoecocestus hydrochoeri and M. jacobi, with the parameters of prevalence (Table 1), mean intensity (Table 2), and parasitism's intensity (Table 3 ) in animals between young and adults.

Table 1 - Prevalence of helminths in capybaras Hydrochoerus hydrochaeris L. 1766 in Granja Santa Maria, Rio Grande, RS, Brazil.

\begin{tabular}{|c|c|c|c|}
\hline Species & $\begin{array}{c}\text { General } \\
\mathbf{n}=\mathbf{2 4}\end{array}$ & $\begin{array}{c}\text { evalence } \\
\text { Young's } \\
\text { n=12 } \\
\end{array}$ & $\begin{array}{c}\text { Adults } \\
\mathrm{n}=12\end{array}$ \\
\hline \multicolumn{4}{|l|}{ NEMATODA } \\
\hline Strongyloides sp. & $62.5^{\mathrm{i}}$ & $66.67^{\mathrm{b}}$ & $58.33^{\mathrm{i}}$ \\
\hline P. obesa & $95.83^{\mathrm{a}}$ & $100.00^{\mathrm{a}}$ & $91.67^{\mathrm{a}}$ \\
\hline V. hydrochoeri & $70.83^{\mathrm{i}}$ & $66.67^{\mathrm{b}}$ & $75.00^{\mathrm{a}}$ \\
\hline H. anomalobursata & $58.33^{\mathrm{i}}$ & $58.33^{\mathrm{b}}$ & $58.33^{\mathrm{i}}$ \\
\hline Trichostrongylidae $^{1}$ & $75.00^{\mathrm{i}}$ & $66.67^{\mathrm{b}}$ & $83.33^{\mathrm{a}}$ \\
\hline C. hydrochoeri & $83.33^{\mathrm{a}}$ & $75.00^{\mathrm{a}}$ & $91.67^{\mathrm{a}}$ \\
\hline Trichuris spp. & $50.00^{\mathrm{i}}$ & $66.67^{\mathrm{b}}$ & $33.33^{\mathrm{b}}$ \\
\hline \multicolumn{4}{|l|}{ TREMATODA } \\
\hline H. hippocrepis & $62.50^{\mathrm{i}}$ & $50.00^{\mathrm{b}}$ & $75.00^{\mathrm{a}}$ \\
\hline T. schistocotyle & $12.50^{\mathrm{b}}$ & & $25.00^{\mathrm{b}}$ \\
\hline H. cabrali & $45.83^{\mathrm{i}}$ & $33.33^{\mathrm{b}}$ & $58.33^{\mathrm{i}}$ \\
\hline \multicolumn{4}{|l|}{ CESTODA } \\
\hline M. hydrochoeri & $50.00^{\mathrm{i}}$ & $66.67^{b}$ & $33.33^{\mathrm{b}}$ \\
\hline M. jacobi & $41.67^{\mathrm{i}}$ & $50.00^{\mathrm{b}}$ & $33.33^{\mathrm{b}}$ \\
\hline
\end{tabular}

(1) Females of $V$. hydrochoeri and H. anomalobursata; (a) high parameter for the species; (i) intermediate parameter level for the species; (b) low parameter for the species; 
Significant differences $(\alpha,<0,05)$ were observed between young and adults for $M$. hydrochoeri, Strongyloides sp., Trichuris spp., H. hippocrepis and $H$. cabrali in the mean intensity of parasitism, where M. hydrochoeri, Strongyloides sp. showed the highest values for the young animals and Trichuris spp., $H$. hippocrepis and $H$. cabrali for the adults. There was no significant difference for the others helminths in prevalence and among the species, no observed significant differences was found for the abundance and prevalence. Taxorchis schistocotyle only occurred in adult animals.

\section{DISCUSSION}

Between the eleven helminths, the Protozoophaga obesa was the species, which showed the highest prevalence, mean intensity and abundance. The prevalence $(95.83 \%)$ was the highest than reported by Nascimento et al. (1991), (66.66\%) and near to that found by Sinkoc et al. (2004), (85,71\%), Ribeiro and Amato (2003) (94.44\%) and inferior to that reported by Costa and Catto (1994), Salas and Herrera (2004) and Casas et al., (1996) $(100 \%)$. The mean intensity (2698.26) was lowest than the one observed by Costa and Catto (1994), (7212). However, higher than those reported by Ribeiro and Amato (2003), (709) and Nascimento et al.(1991), (376) and similar to the results of Salas and Herrera (2004)(2663).

The highest levels of prevalence and mean intensity of parasitism be justified by the high amount of eggs produced by the female of $P$. obesa, and the agglutination which occured with the eggs mass, providing viability for the infection (Ribeiro and Amato, 2003). The morphologic characteristics of the eggs, with their thick rind added to the agglutinated substance which could guarantee their environment resistance (Ribeiro and Amato, 2003). P. obesa could be a symbiont rather than a parasite because it are present in high numbers in all capybaras sampled in different countries (Salas and Herrera, 2004). The values of prevalence and mean intensity found by Strongyloides (62.5\% e 168,67 respectively) was different from that reported by Costa and Catto (1994) by S. chapini (47.8\% e 1014) and Sinkoc et al., (2004) (28.71\%). A significant difference in the mean intensity between the ages of the animals was observed, the adults showed highest values, witch disagreed with Costa and Catto (1994) that observed significant values of prevalence and abundance for young animals. Results suggested that a significant difference in mean intensity between the ages of the animals occurred by a hight intensity (1375 worms) in one adult animal. This high intensity can occurr by a imunosuppressed animal out of familiar group of capybaras.

Among the Trichostrongylidae males of Vianella hydrochoeri and Hydrochoerisnema anomalobursata the females could not be specifically identified. Vianella hydrochoeri, was previously detected by Sinkoc et al. (1995) in a nearby area However, the prevalence observed was inferior than reported in other studies performed in Brazil, which showed a variation between 88.88 to $100 \%$ (Arantes et al., 1985; Nascimento et al., 1991; Costa and Catto, 1994, Sinkoc et al., 2004) although with inferior values to that reported in Bolivia in order of $2 \%$ (Casas et al., 1995), and was superior than reported in Venezuela (100\%) (Salas and Herrera, 2004) The intensity of parasitism (83.82) was inferior that observed by Arantes et al., (1985), which was 961 specimens, 135 by Nascimento et al., (1991) and 1031 by Costa and Catto, (1994) and inferior than reported by Salas and Herrera (2004) with 6275 specimens. The prevalence of Hydrochoerisnema anomalobursata was $58.33 \%$, a close value than observed by Nascimento et al., (1991) and inferior to that found by Arantes et al., (1985) which was $100 \%$. The mean intensity (57.86) was inferior than Arantes et al., (1985) and Nascimento et al., (1991), wich were 348 and 184, respectively. The females of both these species showed $75 \%$ of prevalence and 144.44 of mean intensity (Table 1 and 2). Despite of the occurrence of Trichostrongylidae of ruminants in capybaras, and the occurrence of Trichostrongylus and other trichostrongylidae worms in farm animals in the study area, in the present study species of Trichostrongylidae of ruminants in capybaras was not found. This indicate the low interaction betwen capybaras and farm animals in the study area.

Capillaria hydrochoeri showed the highest prevalence $(83.33 \%)$, although lowest was reported by Sinkoc et al., (2004), (100\%) and Costa and Catto (1994), (86.9\%), which observed significant differences between young and adult animals. 
Table 2 - Mean intensity of helminths in capybaras Hydrochoerus hydrochaeris L. 1766 in Granja Santa Maria, Rio Grande, RS, Brazil.

\begin{tabular}{|c|c|c|c|}
\hline \multirow[b]{2}{*}{ Species } & \multicolumn{3}{|c|}{ Mean Intensity } \\
\hline & $\begin{array}{c}\text { General } \\
\mathbf{n}=\mathbf{2 4}\end{array}$ & $\begin{array}{c}\text { Young's } \\
n=12\end{array}$ & $\begin{array}{c}\text { Adults } \\
\mathbf{n}=12\end{array}$ \\
\hline \multicolumn{4}{|l|}{ NEMATODA } \\
\hline Strongyloides sp. & $168.67^{\mathrm{i}}$ & $123.75^{\mathrm{i} *}$ & $220.00^{i} *$ \\
\hline P. obesa & $2698.26^{\mathrm{a}}$ & $2892.08^{\mathrm{a}}$ & $2486.82^{a}$ \\
\hline V. hydrochoeri & $83.82^{\mathrm{i}}$ & $73.75^{\mathrm{i}}$ & $92.78^{\mathrm{i}}$ \\
\hline H. anomalobursata & $57.86^{\mathrm{i}}$ & $70.00^{\mathrm{i}}$ & $45.71^{\mathrm{i}}$ \\
\hline Trichostrongylidae $^{1}$ & $144.44^{\mathrm{i}}$ & $148.75^{\mathrm{i}}$ & $141.00^{\mathrm{i}}$ \\
\hline C. hydrochoeri & $35.25^{\mathrm{i}}$ & $47.22^{\mathrm{i}}$ & $25.45^{\mathrm{i}}$ \\
\hline Trichuris spp. & $36.58^{\mathrm{i}}$ & $47.88^{i} *$ & $14.00^{\mathrm{i}} *$ \\
\hline \multicolumn{4}{|l|}{ TREMATODA } \\
\hline H. hippocrepis & $22.40^{\mathrm{i}}$ & $10.00^{\mathrm{b} *}$ & $30.67^{i} *$ \\
\hline T. schistocotyle & $2.33^{\mathrm{b}}$ & - & $2.33^{\mathrm{b}}$ \\
\hline H. cabrali & $10.73^{\mathrm{i}}$ & $7.00^{\mathrm{b}} *$ & $12.86^{\mathrm{i} *}$ \\
\hline \multicolumn{4}{|l|}{ CESTODA } \\
\hline M. hydrochoeri & $28.25^{\mathrm{i}}$ & $32.75^{\mathrm{i} *}$ & $19.25^{\mathrm{i} *}$ \\
\hline M. jacobi & $5.40^{\mathrm{i}}$ & $4.83^{\mathrm{b}}$ & $6.25^{\mathrm{i}}$ \\
\hline
\end{tabular}

Table 3 - Parasitism intensity of helminths in capybaras Hydrochoerus hydrochaeris L. 1766 in Granja Santa Maria, Rio Grande, RS, Brazil.

\begin{tabular}{|c|c|c|c|c|c|c|}
\hline \multirow{4}{*}{ SPECIES } & \multirow{3}{*}{\multicolumn{2}{|c|}{$\begin{array}{c}\text { General } \\
\mathrm{N}=24\end{array}$}} & \multirow{2}{*}{\multicolumn{2}{|c|}{ Young's }} & \multirow{2}{*}{\multicolumn{2}{|c|}{ Adults }} \\
\hline & & & & & & \\
\hline & & & \multicolumn{2}{|c|}{$\mathrm{N}=12$} & \multicolumn{2}{|c|}{$\mathrm{N}=12$} \\
\hline & $\mathrm{NI}^{1}$ & $\mathrm{NS}^{2}$ & $\mathrm{NI}$ & NS & $\mathrm{NI}$ & $\mathrm{NS}$ \\
\hline \multicolumn{7}{|l|}{ NEMATODA } \\
\hline Strongyloides sp. & 5 & 1375 & 15 & 315 & 5 & 1375 \\
\hline P. obesa & 120 & 5760 & 695 & 5760 & 120 & 5555 \\
\hline V. hydrochoeri & 10 & 255 & 10 & 255 & 25 & 220 \\
\hline H. anomalobursata & 10 & 230 & 10 & 230 & 20 & 85 \\
\hline Trichostrongylidae ${ }^{3}$ & 5 & 490 & 10 & 465 & 5 & 490 \\
\hline C. hydrochoeri & 5 & 110 & 25 & 110 & 5 & 90 \\
\hline Trichuris spp. & 2 & 249 & 2 & 249 & 2 & 28 \\
\hline \multicolumn{7}{|l|}{ TREMATODA } \\
\hline H. hippocrepis & 1 & 131 & 1 & 27 & 1 & 131 \\
\hline T. schistocotyle & 1 & 2 & - & - & 1 & 2 \\
\hline H. cabrali & 1 & 48 & 2 & 14 & 1 & 48 \\
\hline \multicolumn{7}{|l|}{ CESTODA } \\
\hline M. hydrochoeri & 1 & 115 & 2 & 115 & 1 & 67 \\
\hline M. jacobi & 1 & 14 & 1 & 11 & 1 & 14 \\
\hline
\end{tabular}

(1) Inferior level; (2) superior level; (3) Females of V. hydrochoeri and H. Anomalobursata; 
This was not observed in the present study. The mean intensity of parasitism observed (35.25) was lower was reported for Mato Grosso (Brazil) (156) by Costa and Catto (1994).

The Trichuris spp was found for the first time in capybaras with $50 \%$ of prevalence, and showed a significant difference between the young and adults (Table 1). In the State of Rio Grande do Sul (Brazil) T. travassosi was cited in Oryzomys nigripes and Trichuris sp. in Myocastor coypus; in farm animals $T$. ovis, $T$. globulosa and T. skrjabini in sheep, T. ovis and T. discolor in cattle (Oliveira and Gonzales, 1990, Gomes et al., 1992; Paulsen, 1998). The low mean intensity and mean prevalence suggesting that Trichuris spp accidentally occuring in capybaras, originally of another host as farm animals or wild nutrias living in the same área. This was supported by findings of Trichuris in nutrias of same area with prevalence of $87.5 \%$ and mean intensity of 18.18 worms (Paulsen, 1998).

The prevalence values observed for the helminths with direct cycle in the present study and their variation with the values observed by other authors be explained by the environmental conditions, can the weather conditions and biological factors that onto vary according to the seasons (Stromberg, 1997), in addition to capybara social behavior, which produce interactions between the animals, presented variability in the size of the group according the season (Alho, 1987a,b) and that animals which show a group behavior the size of the group influenced the level of parasitism prevalence with high specificity. Also the parasites with direct cycle canto have their distribution affected by this behavior (Ezenwa, 2004).

The prevalence observed for Hippocrepis hippocrepis $(62.5 \%)$ was inferior thas reported by Salas and Herrera (2004) (80\%) and was high than reported by Casas et al., (1995) in Bolivia (20\%), Sutton et al., (1995) in Argentina (52.9\%) and Pantanal, Mato Grosso (Brazil) by Costa and Catto (1994), which considered this species potentially pathogenic because their higher mean intensity of parasitism (3832), prevalence (34.8\%) and the fixation of the parasites in the mucosa in cecum and colon of the host. Although in the present study, this helminths found fixed in the mucosa, the intensity level of parasitism was lower $(22,4)$ than reported for the Pantanal, (Costa and Catto, 1994) and Venezuela (Salas and Herrera, 2004 $(51,25)$.
The Taxorchis schistocotyle was observed parasitizing the cecum in $12.50 \%$ of the animals, however only in adults with a parasitism intensity of 2,33 specimens. In the State of São Paulo Sinkoc et al. (2004) observed the prevalence of $42.86 \%$ for this species, whereas Costa and Catto (1994) reported 56.5\% in Pantanal, Casas et al., (1995) $12 \%$ in Bolivia, Salas and Herrera (2004) $83 \%$ in Venezuela and in commercial production in Santo Antonio da Patrulha, RS (Ribeiro, 2002) with a prevalence of $3,33 \%$.

The trematode Hydrochoeristrema cabrali presented $45.83 \%$ of prevalence and mean intensity of 10.73 helminths. After that this species was observed in capybaras in the State of Sao Paulo (Sinkoc et al., 2004) with prevalence of $28.57 \%$ and in animals for human consum (Tancredi et al. 2004). The presence of digeneans in wild capybaras from farm areas, the values of prevalence and mean intensity denoted the occurrence of intermediate hosts of those species in this habitat; and the possibility of the occurrence of this parasitosis in animals for commercial explotation in this area.

The species of Anoplocephalidae observed in capybaras, Monoecocestus jacobi showed $41.67 \%$ of prevalence and 5,40 of intensity. $M$. hydrochoeri was observed with $50 \%$ of prevalence and parasites mean intensity of 28.25 , while Costa and Catto (1994) in Pantanal ( Mato Grosso) reported a prevalence of $.54 .5 \%$ and in Bolivia (Casas et al., 1995) 12\%. In animals commercial exploitation in the State of São Paulo (Sinkoc et al., 2004) a prevalence of $28.57 \%$ was observed. The presence of this species also was reported in captivities animals in Rio de Janeiro (Brazil) (Mattos Jr. and Sanavria, 1993). Ribeiro (2002) reported prevalences of $14.28 \%$ and $31.25 \%$ and mean intensity of 6.8 and 7.8 parasites, respectively for the males and females in the commercial productions in Rio Grande do Sul. The oribatids mites are usually intermediate hosts of the cestodes (Family: Anoplocephalidae) and the presence of the $M$. hydrochoeri in captivities animals indicated the favorable environmental condition to maintain this and other species of anoplocephalids for the commercial production. Although the parasitism mean intensity was low and in horses, a domestic species, infected by the species of Anoplocephalidae, the severity of the anaplocephalosis directly proportional to the his parasitism intensity (Proudman and Trees, 1999), 
here the presence of this parasite must be carefully observed in commercial productions.

Others related taxonomic helminths found in capybara was reported in the same study area in Myocastor coypus (Hippocrepis fueleborni, $H$. myocastoris, Chiostichorchis walthieri, Hydrochoeristrema massaroi and Monoecocestus myopotami) by Paulsen (1998) and considering that two species possesed intermediate hosts these condition of competition by same conditions result in increase of some species and decrease of others, affected the parameters levels evaluated in the present study.

The variation of the prevalence and mean intensity values of helminths in capybaras as showed in this study, when compared with others authors, was considered by the weather factors, such as humidity and temperature, abundance of intermediate hosts, exposure to infective forms in the environment, the social status in the group and the immunity response of the animals.

\section{RESUMO}

Com o objetivo de observar a prevalência, intensidade e intensidade média de infecção de helmintos gastrintestinais de capivaras foram estudados 24 animais na Granja Santa Maria, região do Banhado do Taim, Município de Rio Grande, RS. As espécies de helmintos coletadas resultaram na seguinte relação, com suas respectivas prevalências e intensidades médias de infecção: Strongyloides sp. - 62,5\% e 168,67; Protozoophaga obesa - 95,83\% e 2698,26; Vianella hydrochoeri - $70,83 \%$ e 83,82; Hydrochoerisnema anomalobursata - 58,33\% e 57,86; Capillaria hydrochoeri - 83,33\% e 35,25; Trichuris spp. - 50,00\% e 36,58; Hippocrepis hippocrepis - 62,50 e 22,40; Taxorchis schistocotyle - $12,50 \%$ e 2,33; Hydrochoeristrema cabrali - $45,83 \%$ e 10,73; Monoecocestus hydrochoeri - 50,00\% e 28,25 e Monoecocestus jacobi - 41,67\% e 5,40. Os helmintos $M$. hydrochoeri, Strongyloides sp., Trichuris spp., $H$. hippocrepis e $H$. cabrali diferiram estatisticamente entre idades na intensidade média de parasitismo, os dois primeiros apresentaram valores mais elevados para animais jovens e os três últimos para adultos.

\section{REFERENCES}

Alho, C. J. R.; Campos, Z. M. S. and Gonçalves, H. C. (1987a), Ecologia de capivara (Hydrochaeris hydrochaeris, Rodentia) do Pantanal: - I Habitats, densidades e tamanho de grupo. Rev. Bras. Biol., 47 : (1/2), 87-97.

Alho, C. J. R.; Campos, Z. M. S. and Gonçalves, H. C. (1987b) Ecologia de capivara (Hydrochaeris hydrochaeris, Rodentia) do Pantanal: - II Atividade, sazonalidade, uso do espaço e manejo. Rev. Bras. Biol., 47 : (1/2), 99-110.

Anderson, R. C. and Chabaud, A. G., (1983) CIH Keys to the nematode parasites of vertebrates, Farnham Royal, England.

Anderson, R. C., Chabaud, A. G. and Willmott, S., (1974-1982.) CIH Keys to the nematode parasites of vertebrates, Farnham Royal, England.

Arantes, I. G., Nascimento, A. A. do, Artigas, P. de T., Macedo, N. A. de. (1985) Trichostrongyloidea Cram 1927 parasitos de capivaras (Hydrochoerus hydrochaeris hydrochaeris Linnaeus, 1766) provenientes do estado do Mato Grosso do Sul, Brasil. Paper presented at $10^{\text {th }}$ Encontro de Pesquisas Veterinárias, Jaboticabal, Brazil.

Casas, M. C.; Zalles, L. M.; Patrick, M. J. and Dailey, M. (1995), Intestinal helminths of capybara (Hydrochaeris (Hydrochoerus) hydrochaeris) from Bolivia. J. Helminthol. Soc. Wash.. 62 : (1), 87-88.

Costa, C. A. F. and Catto, J. B. (1994), Helmintos parasitos de capivaras (Hydrochaeris hydrochaeris) na sub-região da Nhecolândia, Pantanal-sulmatogrossense. Rev. Bras. Biol., 51: (1), 39-48.

Ezenwa, V. O.(2004) Host social behavior and parasitic infection: a multifactorial approach, Behav. Ecol., 15 : (3), 446-454.

Gomes, D. C.; Lanfredi, R. M.; Pinto, R. M. and Souza, W. (1992), Description of Trichuris travassosi n. sp., (Nematoda: Trichurinae) from a Brazilian rodent by ligth and scaning eletron microscopy, Mem. Inst. $O$. Cruz, 87 :(suppl. 1),1-10.

Margolis, L.; Esch, G. W.; Holmes, J. C.; Kuris, A. M. and Schad, G. A. (1982), The use of ecological terms in parasitology (Report of an Ad Hoc Committee of the American Society of Parasitologists), $J$. Parasitol., 68: (1), 131-133.

Mattos Jr, D.G. and Sanavria, A. (1993) Helmintos parasitos de capivaras (Hydrochoerus hydrochaeris) em sistema de criação de cativeiro, no estado do Rio de Janeiro. Paper presented at $8^{\text {th }}$ Seminário Brasileiro de Parasitologia Veterinária, Londrina, Brazil. 
Mattos Jr, D.G.; Sanavria, A. and Tortelly, R. (1993), Ocorrência de Hydrochoerisnema anomalobursata Arantes and Artigas, 1980 (Trichostrongyloidea) em capivaras (Hydrochoerus hydrochaeris) criadas em regime de semi-confinamento, no Estado do Rio de Janeiro. Paper presented at $8^{\text {th }}$ Seminário Brasileiro de Parasitologia Veterinária, Londrina, Brazil.

Nascimento, A. A. do; Tebaldi, J. H.; Ascari, H. and Arantes, I. G. (1991), Helmintos parasitos de Hydrochoerus hydrochaeris hydrochaeris (Linnaeus, 1766) no estado do Mato Grosso do Sul, Brasil. Paper presented at $7^{\text {th }}$ Seminário Brasileiro de Parasitologia Veterinária, São Paulo, Brazil.

Oliveira, C. M. B. and Gonzales J. C. (1990), Fauna Parasitária Riograndense, Arq. Fac. Vet. UFRGS, 18 : 19-59.

Paulsen, R. M. M. (1998), Helmintos e artrópodos parasitos de ratão-do-banhado (Myocastor coypus) em área de exploração agropecuária próxima à Estação Ecológica do Taim, Município de Rio Grande - RS. MSc Thesis, Universidade Federal de Pelotas, Pelotas, Rio Grande do Sul, Brazil.

Proudman, C. J. and Trees, A. J. (1999), Tapeworms as a cause of intestinal disease in horses, Parasitol. Today, 15: (4), 156-159.

Ribeiro, S. M. B. (2002), Helmintos do sistema digestivo de Hydrochaeris hydrochaeris (Linnaeus, 1766) criadas em sistema semi intensivo no município de Santo Antônio da Patrulha, Rio Grande do Sul, Brasil. MSc Thesis, Universidade Federal do Rio Grande do Sul, Porto Alegre, Rio Grande do Sul, Brazil.

Ribeiro, S. M. B. and Amato, S. B. (2003), Estratégia de infecção de Protozoophaga obesa (Diesing, 1851) Travassos, 1923 (Oxyuroidea, Oxyuridae) Arq. Inst. Biol., 70 : (2), 131-133.

Salas, V. and Herrera E. A. (2004), Intestinal Helminths of Capybaras, Hydrochoerus hydrochaeris, from Venezuela, Mem. Inst. O. Cruz, 99: (6), 563-566.

Silva, F. (1994), Mamíferos Silvestres - Rio Grande do Sul, Fundação Zoobotânica do Rio Grande do Sul, Porto Alegre.

Sinkoc, A. L.; Müller. G.; Brum, J. G. W.; Begrow, A. and Delevatti, C. (1995), Helmintos parasitos de capivaras (Hydrochoerus hydrochaeris) na Estação Ecológica do Taim, Rio Grande - RS. Paper presented at $19^{\text {th }}$ Congresso Brasileiro da Sociedade de Zoológicos do Brasil, Foz do Iguaçu, Brazil.
Sinkoc, A. L. (1997), Helmintos gastrintestinais e artrópodos parasitos de capivara Hydrochaeris hydrochaeris (Linnaeus, 1766) em área de exploração pecuária na região do Banhado do Taim, Município de Rio Grande, RS. MSc Thesis Universidade Federal do Rio Grande do Sul, Porto Alegre, Rio Grande do Sul, Brazil.

Sinkoc, A. L.; Brum, F. A., Müller, G. and Brum, J. G. W. (2004), Helmintos parasitos de capivara (Hydrochoerus hydrochaeris L. 1766) na região de Araçatuba, São Paulo, Brasil, Arq. Inst. Biol. 71: (3), 329-333.

Skrjabin, K.I. et al.,(1964) Keys to the Trematodes of Animals and Man,: University of Illinois Press, Urbana.

Stromberg, B. E. (1997) Environmental factors influencing transmission. Vet. Parasitol. 72, 247264.

Sutton, C. A.; Ostrowki de Nuñez, M.; Lunaschi, L. and Allekotte, R. (1995), Digeneos Notocotyloidea en Hydrochaeris hydrochaeris Linne, de Argentina, Paper presented at $12^{\text {th }}$ Congreso Latinoamericano de Parasitologia, Santiago, Chile.

Tancredi, I. P., Silva, R. M., Neves Jr., J. M.and Tancredi, M. G. F. (2004) Levantamento preliminar de endoparasitas ocorrentes em capivaras (Hydrochoerus hydrochaeris) e queixadas (Tayassu pecari) destinados ao abate. Paper presented at $13^{\text {th }}$ Congresso Brasileiro de Parasitologia Veterinária, Ouro Preto, Brazil.

Ueno, H., Gonçalves, P. C. (1994), Manual para diagnóstico das helmintoses de ruminantes. Japan International Cooperation Agency, Tokyo.

Yamaguti, S. (1959), Systema Helmintum : The Cestodes of Vertebrates. Interscience, New York

Yamaguti, S. (1961), Systema Helmintum : The Nematodes of Vertebrates. Interscience, New York

Yamaguti, S. (1971), Synopsis of Digenetic Trematodes of Vertebrates. Keigaku, Tokyo

Received: September 05, 2005; Revised: April 17, 2006; Accepted: November 21, 2008. 